\title{
HUNTER'S POLYDYSTROPHY (GARGOYLISM) WITH CARDIAC LESIONS AND SOME FORMES FRUSTES
}

\author{
BY \\ R. E. STEEN \\ From the Congenital Heart Unit, The National Children's Hospital, Dublin \\ Received August 8, 1958
}

Thompson, the Scottish physician who did so much for the advancement of the study of children's diseases, first described the condition of gargoylism in 1900. His cases were not published until much later (Henderson and Ellis, 1940) and the first recorded description was by Hunter in 1917. Two years later Gertrude Hurler gave an account that appeared in America as Hurler's syndrome. Later Ellis et al. (1936) described further examples and gave it the name of gargoylism because of the particularly ugly appearance of the well-marked case. Other names for the condition, such as dysostosis multiplex and lipochondrodystrophy have no special extra advantage, the latter being possibly misleading as it is controversial whether it should be regarded any longer as a disorder of lipoid metabolism. The term gargoylism, though picturesque and memorable, is rather a wounding one, especially when applied to the formes frustes which show a more normal appearance. It is hoped that in the future the condition will more and more be referred to as Hunter's polydystrophy.

The disease has a genetic origin and two distinct types have been described, one due to a single autosomal recessive gene, the other occurring in males only without corneal involvement and due to a sex-linked recessive gene. The condition is also closely related to other similar dystrophic diseases, achondroplasia with its short limbs, and Morquio's disease with its severe stunting and deformed chest and normal intelligence.

At one time thought to be a lipoidosis, it is now (Dawson, 1954) considered to be a disturbance of polysaccharide or mucopolysaccharide metabolism, the bony changes being dystrophic and secondary to the metabolic derangement.

In the severe case it is easy to see how the term gargoylism became attached. The child is mentally deficient and ugly, the head large, the ears set low, the nasal bridge depressed, and the face generally having a flat appearance. The superciliary ridges are prominent and the eyebrows heavy. The lips are thick and the teeth widely spaced. A chronic rhinorrhœa adds to the facial disfigurement. A "trident" hand such as that described in achondroplasia may be present. Bony changes in the trunk lead to a short neck, dorso-lumbar kyphosis, and a flared thoracic border. Restriction of extension of the elbows and knees may be present, and genu valgum is the rule. The liver and spleen may be enlarged.

The dystrophic bone changes are best seen radiologically in the spine. The first or second lumbar vertebra is deformed due to hypoplasia of the anterior portion of the body giving a striking "hooked" or "beaked" appearance in an X-ray film. In the hips similar dystrophic changes are usually present. Similar changes to these are also seen in achondroplasia, Morquio's disease, and cretinism.

The ophthalmic disorders in Hunter's polydystrophy are pathognomonic. The corneæ are opaque though this may not be obvious to the naked eye. When viewed through the slit-lamp yellowish-white deposits are seen in the middle and deeper layers. These changes may not be 
present during the first year or two of life and, as already mentioned, in the type of Hunter's polydystrophy associated with a sex-linked recessive gene, the changes in the cornex may be absent.

Cardiovascular abnormalities of a degenerative nature have only come into prominence in quite recent times though 85 per cent of necropsies on cases of Hunter's polydystrophy have shown such changes. Emanuel (1954) described necropsies on patients who had murmurs and cardiographic abnormalities during life. All four valves (though more usually only the aortic and pulmonary) showed thickening and rigidity of the cusps, due to dense poorly-cellular fibrous tissue, and hyaline degeneration with gelatinous nodules. The coronary arteries were abnormal, standing out as thickened white cords due to nodular thickening, and histologically showing subintimal fibrosis causing narrowing of the lumen. Craig (1954) described similar changes in the mitral valve, myocardium, and coronary vessels, and in one case typical anginal attacks for two years before death.

Formes frustes have also been described in which only some of the features mentioned have been present; for example, there may be an absence of the typical ugly appearance and an absence of mental deficiency. The present three cases fall into this group. In a search through previously published reports I have been unable to find instances of formes frustes with cardiac lesions but a relatively normal appearance and normal mentality.

\section{CASE REPORTS}

The three patients, T.C., M.C., and G.C., who form the family presented here are three boys, twins now aged $8 \frac{1}{2}$ years old and a boy aged 7 years. The first child, T.C., one of the twins, was referred to me by Dr. Euphan Maxwell in March, 1954, because the school medical officer thought his vision was slightly defective. This proved to be due to slight astigmatism and the dystrophic changes would have been missed, had not Dr. Maxwell, when the pupils were dilated for retinoscopy, noted slight haziness of both corneæ and a greater rise of tension in the eyes than would be usual, causing her to make a closer examination with the slit-lamp. He was subsequently referred to me at the National Children's Hospital, Dublin. The other children were then investigated. There were no other cases in the family history. All three children presented the typical ocular features of Hunter's polydystrophy. This was confirmed by a number of ophthalmologists, including Arnold Sorsby, when the cases were shown at the Irish Ophthalmological Society's annual meeting in 1955.

On general physical examination (Fig. 1) all three children have in slight degree a number of the features of Hunter's polydystrophy: the big heads, the depressed nasal bridges, the ears set low, the rather flat faces, the flared thoracic borders, and the genu valgum. G.C. also showed a tendency to a "trident" hand such as one sees in achondroplasia. The livers and spleens were not enlarged.

On radiological examination all three showed conspicuous chondro-dystrophic changes best seen in the spines where the typical deformity of the anterior portion of the second lumbar spine with the characteristic "hooked" or "beaked" effect was found (Fig. 2). The hip-joints also showed irregular mineralization, flattening of the epiphyses of the femoral heads, and shallow acetabulæ (Fig. 3). The pituitary fossæ were normal.

Examination of the heart disclosed in each child abnormalities that had not previously been observed. In T.C. there were systolic and diastolic murmurs at the apex, and a systolic murmur at the aortic area; in M.C. a presystolic murmur at the apex, and a systolic murmur in the aortic area; and in G.C. a loud apical systolic murmur conducted to the axilla, and a systolic murmur in the aortic area. These are shown in the phonocardiograms (Fig. 4, 5, 6, and 7).

Radiologically the hearts were within normal limits, except that G.C.'s suggested slight generalized enlargement. The three electrocardiograms and sphygmograms were within normal limits. The rest of the physical examination, including that of the nervous system, gave normal results in each instance.

The blood biochemistry has been normal in all three cases. This included the blood proteins (both quantitatively and by electrophoresis, chromatograms showing normal albumin, alpha ${ }_{1}$, 


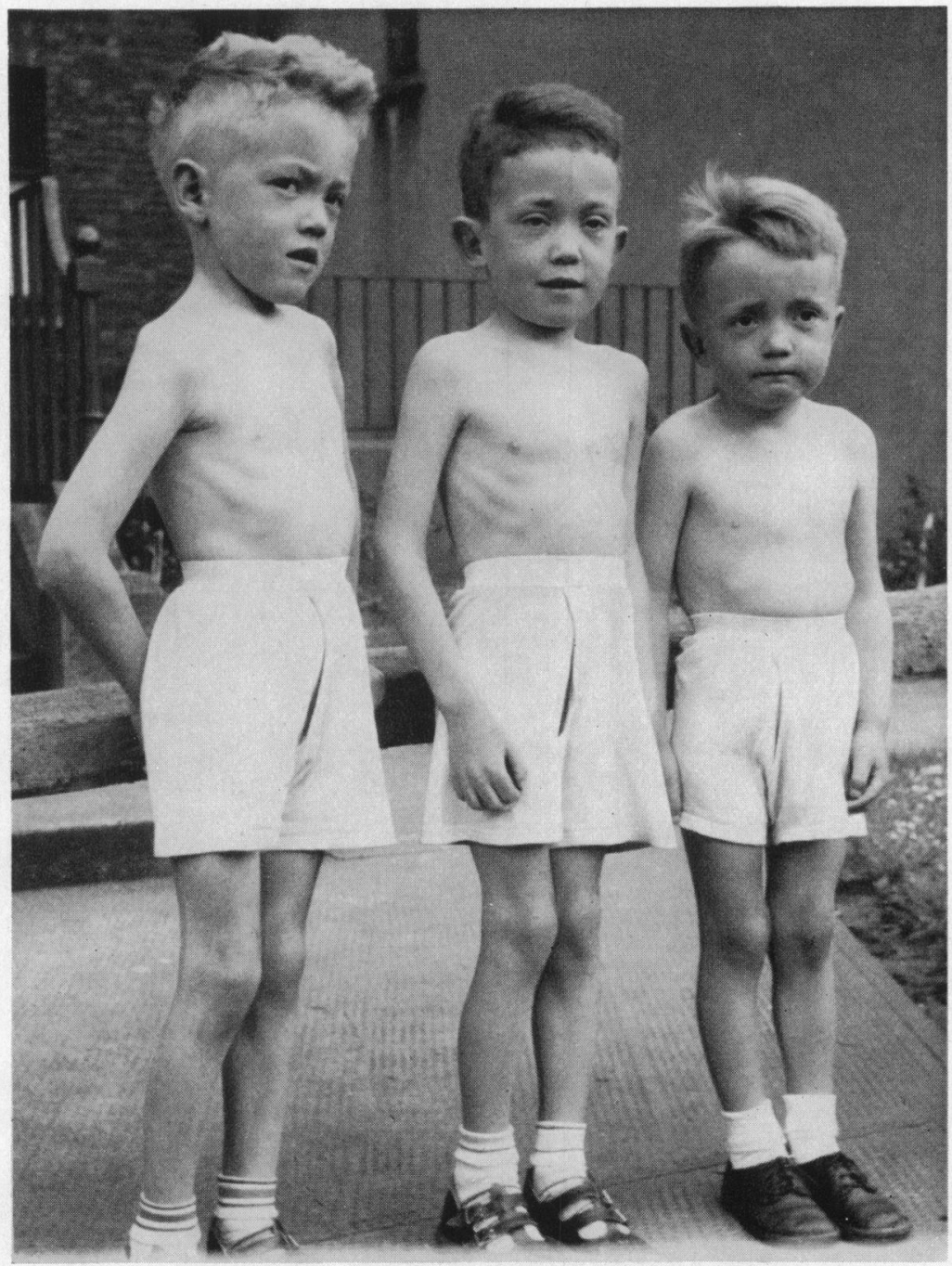

FIG. 1.-Hunter's polydystrophy (formes frustes) T.C., M.C., and G.C., showing the big heads, the depressed nasal bridges, the ears set low, the rather flat faces, the flared thoracic borders, and the ganu valgum.

alpha $_{2}$, beta, and gamma globulin ratios) blood urea, calcium, phosphorus, and cholesterol. Latest cholesterol figures give rather high normal figures. Hæmatological and urinary findings were normal. The blood pressures were normal. The most recent heights are $4 \mathrm{ft} .1$ inch, $4 \mathrm{ft} .0$ inch, and $3 \mathrm{ft}$. 10 inches: these figures are average for their ages. The children are quite normal from the mental point of view, the twins having intelligence quotients of 113 and 101 and the youngest child an exceptionally good I.Q. of 134 .

\section{Differential Diagnosis}

The presence of lesions in the corneæ absolutely pathognomonic of Hunter's polydystrophy would make any differential diagnosis seem superfluous. Achondroplasia, which can be associated with cardiac lesions and chondrodystrophy, has on the other hand the typical short limbs and no corneal lesions. Morquio's disease with its severe stunting and deformities of the chest and normal 


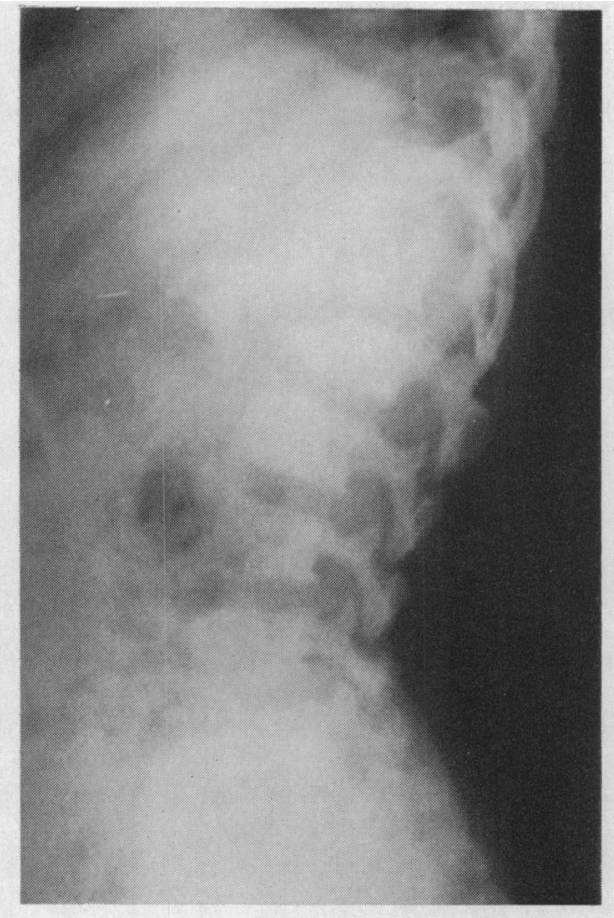

FIG. 2.-Hunter's polydystrophy (formes frustes), showing chondro-dystrophic changes in the lumbar spines and typical "hooked" or "beaked" deformity in the anterior portion of the 2nd lumbar spine.

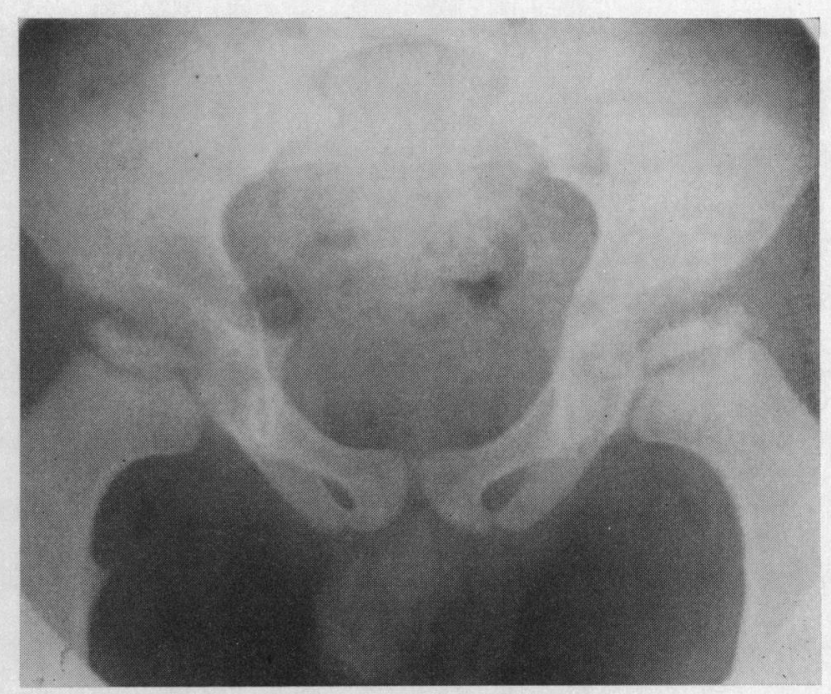

Fig. 3.-Hunter's polydystrophy (formes frustes), showing chondro-dystrophic changes in the hip-joints with irregular mineralization, flattening of the epiphyses of the femoral heads, and shallow acetabula.

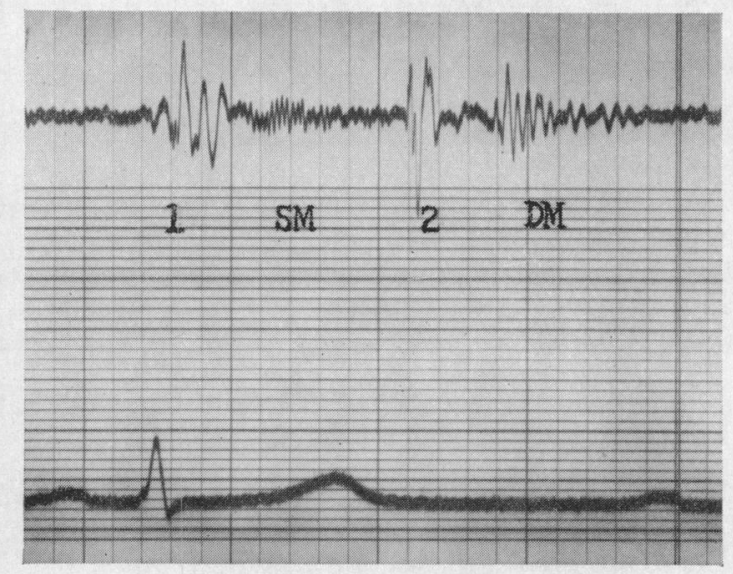

FIG. 4.-Hunter's polydystrophy (formes frustes) T.C. phonocardiogram, showing apical systolic and diastolic murmurs.

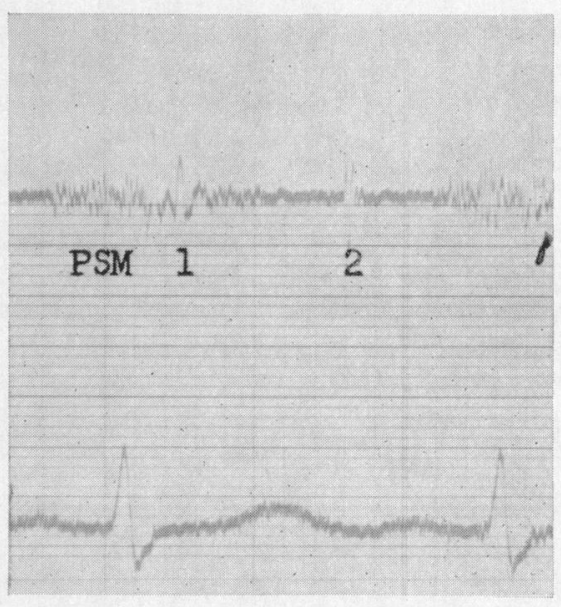

FIG. 5.-Hunter's polydystrophy (formes frustes) M.C. phonocardiogram, showing apical presystolic murmur. 


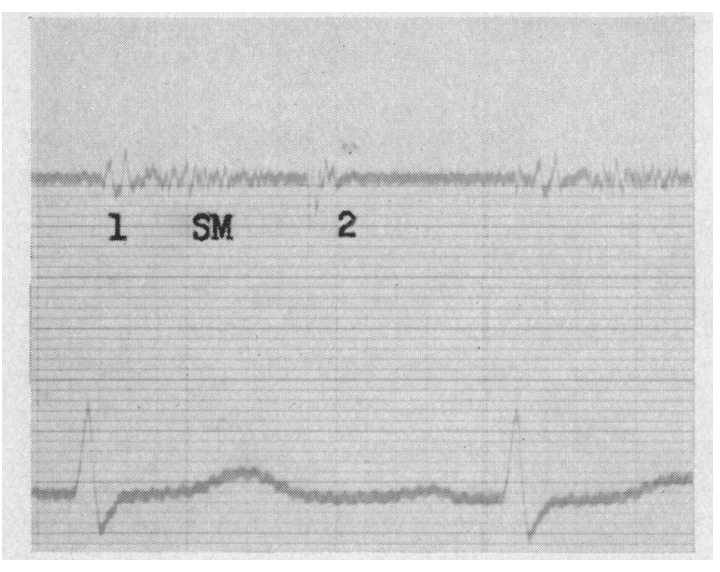

Fig. 6.-Hunter's polydystrophy (formes frustes) M.C. phonocardiogram, showing aortic systolic murmur.

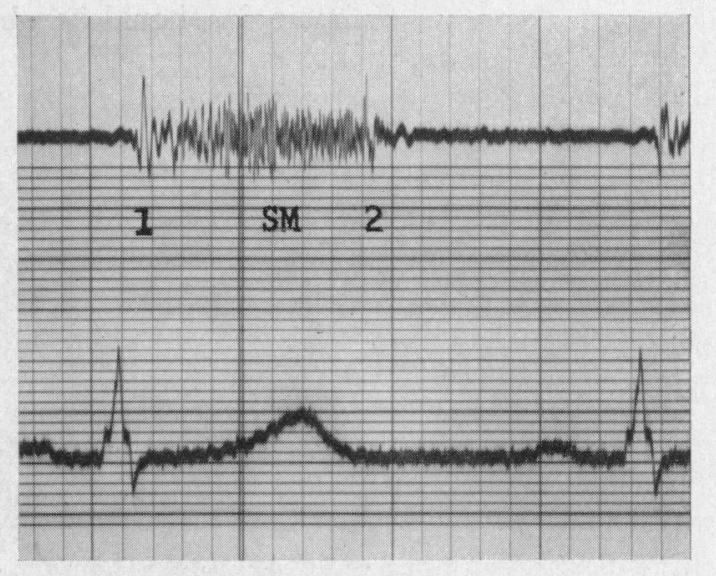

FIG. 7.-Hunter's polydystrophy (formes frustes) G.C. phonocardiogram, showing apical systolic murmur.

intelligence also shows chondrodystrophy, but cardiac lesions have not been described in this condition, and corneal lesions do not occur. Cretinism also shows chondro-dystrophy and cardiac abnormality, but the latter is quite different from that of Hunter's polydystrophy, and in addition in cretinism there are the characteristic biochemical changes in the blood but no corneal lesions. Congenital syphilis presents a totally different picture, and this infection does not often cause acquired cardiac disease in childhood. The lesions in the eyes are entirely different, and one would expect the W.R. and Kahn to be positive and not negative as in these three children. Cystinosis and Turner's syndrome have their characteristic features. While idiopathic hypercalcæmia, the Fanconi syndrome, and fibro-elastosis are associated with heart disease, they have not been described in association with the chondrodystrophy of Hunter's polydystrophy nor with the corneal lesions.

\section{Prognosis AND Treatment}

The prognosis in these cases is precarious but not hopeless. From the point of view of the eyes, Wilfrid Sheldon (personal communication) considers that the corneal lesion, which is not usually seen until one to two years old, need not necessarily progress to serious defective vision, and in one of Craig's cases the eye lesions seemed to become static. There is therefore some reason to hope that the cardiac lesions might behave in a similar way. Over several years, there has been no obvious deterioration radiologically or electrocardiographically. On the other hand, the presystolic murmur in the case of M.C. was less audible then, and G.C.'s mitral systolic murmur which was then only audible in the mid-axilla can now be heard as far as the scapular line. Nevertheless, it is hoped that a spontaneous remission is still possible.

For these patients treatment can only be symptomatic.

\section{Discussion AND ConClusions}

Though the gross case of Hunter's polydystrophy should be unmistakable, there is a danger of mistaking the cardiac features of these formes frustes for some other cardiac disease, for example, juvenile rheumatism, and in consequence long and unnecessary treatments may be prescribed. It is even possible, as Sorsby suggested (personal communication), that the formes frustes may be the more common, and the grosser type the rarer condition. Even if this is not so, any patient with an atypical cardiopathy, especially if any of the minor stigmata of Hunter's polydystrophy are suggested, should have the spine X-rayed for chondro-dystrophy. If the diagnosis remains doubtful the 
opinion of an ophthalmologist should be obtained. In the sex-linked recessive form, in which corneal lesions are said to be absent, the diagnosis would have to be made by the clinical features and the exclusion of the other causes of chondro-dystrophy.

While attention has been drawn to the danger of mistaking the cardiac lesions in these formes frustes of Hunter's polydystrophy for other cardiac conditions, it must be remembered that these cases may also help to distinguish and show the relationship between the dystrophic genetic disorders and the biochemical syndromes that have been described so frequently of late, in particular the "severe type of idiopathic hypercalcæmia". It is admitted that Hunter's polydystrophy, Morquio's disease, and achondroplasia are near relatives. Again, various authors, for example Schlesinger et al. (1952, 1956), and Lowe et al. (1954), describing the severe type of idiopathic hypercalcæmia have referred to an unusual facies with low-set ears ("elfin" appearance) resembling the "affronted incredulous expressions of Pekinese dogs". This description is reminiscent of the facies of Hunter's polydystrophy and cases of idiopathic hypercalcæmia have also been associated with cardiac lesions. Furthermore, it was suggested (Fanconi et al., 1952) that "inherited congenital anomalies" might explain the latter syndrome. The combinations of clinical features in some of these syndromes may be likened to variations of the same theme played on different instruments. Though the three children described here had normal levels of blood calcium it remains possible that these may at times be higher than normal. The spontaneous recovery in certain cases of idiopathic hypercalcæmia might then be explained by the genetic defect righting itself as the infantile kidney matures. Further research into these disorders is needed, in conjunction with critical appraisal of earlier publications.

\section{SUMMARY}

A description is given of a family containing three children afflicted with Hunter's polydystrophy (gargoylism) and with cardiac lesions, although they were normal mentally, and did not show the typical ugly appearance (formes frustes).

The diagnosis can be made by noting minor stigmata of the condition, by radiological examination of the lumbar spine for the characteristic chondro-dystrophy, and by expert examination of the eyes for the typical changes in the cornex. The latter may only be visible under the slit-lamp.

The importance of not mistaking the cardiac lesions for those of some other cardiac condition, especially juvenile rheumatism, is stressed.

It is suggested that cases such as these may constitute a link between certain genetic dystrophic disorders, for example, Hunter's polydystrophy and achondroplasia which are accepted as closely related to each other and in which cardiac lesions have been described, and other recently described syndromes, especially the "severe type of idiopathic hypercalcæmia" where a somewhat similar facies to that seen in Hunter's polydystrophy has been noted, and where cardiac lesions have also been described.

\section{REFERENCES}

Craig, W. S. (1954). Arch. Dis. Childh., 29, 293.

Dawson, I. (1954). J. Path. Bact. In the press (Cases 2 and 4).

Ellis, R.W. B., Sheldon, W., and Capon, N. B. (1936). Quart. J. Med., 29 (N.S. 5), 119.

Emanuel, R. W. (1954). Brit. Heart J., 16, 417.

Fanconi, G., Girarder, P., Schlesinger, B. E., Butler, N. R., and Black, J. A. (1952). Helv. paediat. Acta, 7, 314

Henderson, J. L., and Ellis, R. W. B. (1940). Arch. Dis. Childh., 15, 201.

Hunter, E. (1917). Proc. Roy. Soc. Med., 10, Sect. Dis. Childh., 104.

Lowe, K. G., Henderson, J. L., Park, W. W., and McGreal, D. A. (1954). Lancet, 2, 101.

Schlesinger, B. E., Butler, N. R., and Black, J. A. (1952). Helv. paediat. Acta, 7, 335.

- - _ - - (1956). Brit. med. J., 1, 127. 